\title{
COMENTÁRIO AO ARTIGO "LA PÓLIS, EL ESTADO Y LOS \\ CIUDADANOS DE LA DEMOCRACIA ATENIENSE COMO UNA COMUNIDAD INDIVISA"
}

Norberto Luiz Guarinello ${ }^{1}$

O artigo do Prof. Dr. Diego Paiaro é uma interessante e mais que contemporânea discussão sobre a pólis grega - de modo muito particular, é verdade -, a Atenas Clássica e sua "democracia” no século V a.C. A problemática na qual se coloca o texto é plenamente atual e relevante: qual o papel possível dos estados-nacionais contemporâneos como núcleos de ação e decisão política em um mundo aparente e crescentemente globalizado?

Diego aborda a questão, a meu ver, sob três ângulos distintos. Era a Atenas Clássica um Estado, como "nós" pensamos o Estado? Como alternativa, agiam seus membros sem atender a lideranças e atuando de forma indivisa? Por fim, podemos pensar essa sociedade por outros ângulos, utilizando, por exemplo, contribuições da antropologia?

Minhas respostas são mais a título de provocação a um texto extremamente rico. Em primeiro lugar, gostaria de ressaltar que a cidade e o período estudados são completamente atípicos, como Geoffrey de St. Croix teve uma vez a oportunidade de ressaltar. Atenas no século V a.C. não existiu em um vácuo de outras estruturas sociais, mas em um contexto altamente determinado pelas conexões, trocas e guerras que dominaram o Mediterrâneo Oriental nesse período. A história de Atenas nesse século pode ser vista, como já o foi, como uma variante sem grande relevância na periferia do grande Império Persa. Só como argumento de mais peso, caberia refletir sobre o que seria o desenvolvimento da politeia de Atenas no século V a.C. sem a Liga de Delos. Mas os exemplos poderiam se multiplicar facilmente: a própria construção de uma frota - tomada por uma assembleia - não foi uma decisão estatal, envolvendo pessoas, recursos, bens materiais adquiridos e geridos por pessoas, é verdade, mas a serviço da pólis?

Muitas dessas questões dizem respeito, é verdade, à existência de Atenas como Estado no sentido atual. Mas qual é esse sentido? Atenas nesse período

\footnotetext{
${ }^{1}$ Universidade de São Paulo, Departamento de História. E-mail: guarinel@usp.br
} 
(arbitrariamente restringido, diga-se de passagem) não foi um Estado como as cidades mesopotâmicas do IV milênio a.C. ou da península itálica no período dito do "Renascimento". Foram formas de organização específicas - em alguns pontos que não tocarei aqui - sim, em outros pontos, não. Contudo, reduzir a acepção de Estado à sua forma mais simplista e weberiana, como o monopólio das formas legítimas de coerção sobre e contra uma sociedade civil independente e com existência à parte, é reduzir tanto o Estado como o próprio Weber a denominadores muito primários. Weber está, nessa passagem em especial, fazendo clara alusão à transição do poder pessoal dos senhores feudais ao Estado absolutista. Mesmo na Atenas do século V a.C. a reivindicação de direitos entre civis ou o ressarcimento de danos sofridos por terceiros não dependia do apoio de amigos ou familiares. O processo de constituição de uma instância jurídica que fugia à lógica da vingança remontava, ao menos, a Dracon. A Constituição de Atenas de Aristóteles e inúmeras outras fontes de caráter jurídico ou não dão conta de instituições concretas, reais e efetivas que levavam a cabo as determinações de outras instituições, como a boulé, os tribunais, os Onze ou os escravos públicos denominados "citas" (responsáveis pela aplicação de penas públicas). Que esses instrumentos não pessoais (essas posições institucionais) foram eficazes, as fontes nos mostram mais de uma vez. O Estado autônomo, burocrático e impessoal de Weber tem muito mais relação com o Estado capitalista desenvolvido (e com sua crítica do próprio) do que com as instituições coercitivas, mas também construtivas, dos Estados antigos. Desse modo, a visão de Weber relaciona-se incomensuravelmente mais à visão de Estado de Hegel ou de Marx do que o próprio Weber gostaria de assumir, creio eu.

Daí deriva uma segunda discordância fundamental com o professor Diego. Atenas nunca foi uma sociedade igualitária, mesmo que para forçá-la nesses limites tenhamos que excluir os escravos (aparentemente, pelo texto, os únicos sujeitos de coerção), as mulheres e os estrangeiros. A democracia ateniense nunca foi uma democracia de sujeitos plenamente iguais. Em primeiro lugar, se tomarmos como significativo o período escolhido pelo autor como "desenvolvimento, apogeu e crise" do sistema democrático em Atenas, veremos que este nunca deixou de estar em crise. Basta mencionar os dois grandes golpes oligárquicos, os conflitos dentro da própria oligarquia, as mudanças de politeia, as sucessivas restrições do corpo de cidadãos, a presença de hetairiai, os atentados e, sobretudo, diria eu, a manutenção de um princípio claramente timocrático na democracia. As trierarquias, as coregias, os 
patrocínios de festividades públicas não eram apenas imposições sobre os mais ricos, mas ofereciam-lhes também prestígio e dividendos políticos. Além disso, mesmo no auge da democracia, certos cargos públicos permaneciam vinculados à renda do cidadão. Daí minha última questão: a da liderança com um corolário aparente, a ausência de Estado.

O autor compara a fugacidade das lideranças atenienses com aquelas observadas por Pierre Clastres num conjunto de ensaios publicado sob o título $A$ Sociedade Contra o Estado. Trata-se, a bem dizer, de uma salutar tentativa de estabelecer paralelos antropológicos com os antigos gregos, para, por assim dizer, retirar sua aparente modernidade. Mas a comparação não se sustenta. Clastres trabalha com sociedades das terras baixas da América do Sul de modo muito engenhoso, mas com dois níveis evidentes de complexidade: em um primeiro nível, sociedades demograficamente frágeis nas quais predominam a poliandria e a fluidez quase absoluta do líder, em geral, o melhor orador, o melhor caçador, o melhor guerreiro; e, em um segundo nível, completamente distinto, os tupi-guarani, com demografia densa, guerras constantes, disputas por territórios, chefias que emergem das grandes aldeias - quase confederações. É nessas sociedades complexas (ou, em termos comparativos, em processo adiantado de complexificação) que Pierre Clastres identifica, como processos de "sociedade contra o Estado", os conhecidos movimentos messiânicos de grupos tupi-guarani em busca da terra sem mal. Da terra, ressalta Clastres, "sem o UNO”. Sirva-nos esta frase, cunhada pelo autor, como sugestão final: Clastres afirma que para o filósofo grego Heráclito o "Uno era o bem"; já para as sociedades indígenas complexas da América das terras baixas o "Uno era o mal”. Se o Uno era o Estado com seus males para o profeta tupi, como supõe Clastres, por que não seria o mesmo, com seus benefícios (como a ausência de stasis), para Heráclito?

Em suma, a despeito e em respeito à vasta bibliografia sobre o tema, não há como negar que a cidade mediterrânea, ou seja, de modo mais amplo, as comunidades que se organizaram ao redor do Mediterrâneo a partir da Idade do Ferro, não poderiam tê-lo feito sem instituições mais ou menos estáveis que dessem conta de seus conflitos internos (muitas vezes dilacerantes) e externos (outras tantas aniquilantes). Podemos nos referir, se preferível for, a essas instituições (como organizações que perfuram no tempo), como fronteiras, que estabelecem o justo agir. O poder nessas instituições nunca foi exercido de modo a-pessoal (o que seria impossível, pois não são entidades metafísicas, não são agentes que independem de pessoas), mas foi, no entanto, um 
Mare Nostrum, ano 2018, v. 9, n. 2

poder que se sobrepôs, de modo direto, às vontades pessoais, às forças das famílias e a das linhagens.

Comentário recebido em 23.07.2018, aprovado em 26.07.2018. 